\title{
EXAMPLE OF GOOD PRACTICE IN SUPPORT EDUCATION OF 3D MODELING AND 3D PRINTING AT ELEMENTARY SCHOOL
}

Vladimír VOCHOZKA*, Katedra aplikované fyziky a techniky, Pedagogická fakulta, Jihočeská univerzita v Českých Budějovicích, Česká republika

Tomáš SOSNA, Katedra aplikované fyziky a techniky, Pedagogická fakulta, Jihočeská univerzita v Českých Budějovicích, Česká republika

Přijato: 3. 2. 2020 / Akceptováno: 18. 6. 2020

Typ článku: Teoretická studie

DOI: $10.5507 /$ jtie.2020.011

Abstract: The article presents a good practice of teaching $3 D$ modeling and $3 D$ printing at an elementary school. The trend of $3 D$ printing penetrates the general public and specialized workplaces. This example can be a recommendation for other primary schools. It is primarily discussed how to design similar teaching and what elements can be used.

Key words: 3D modeling, CAD, 3D printing, FDM, FFM, education, practice.

\section{PŘÍKLAD DOBRÉ PRAXE PRO PODPORU VÝUKY 3D MODELOVÁNÍ A 3D TISKU NA ZŠ}

Abstrakt: Článek poukazuje na ukázku dobré praxe výuky 3D modelování a $3 D$ tisku na konkrétních základnich školách. Trend 3D tisku prostupuje širokou veřejností $i$ specializovanými pracovišti. Uvedený přiklad je možné vnímat jako doporučení pro jiné základní školy. Diskutováno je především jak podobnou výuku koncipovat a jaké prvky je možné použit.

Klíčová slova: 3D modelování, CAD, 3D tisk, FDM, FFM, výuka, praxe.

\footnotetext{
*Autor pro korespondenci: vvochozka@pf.jcu.cz
} 


\section{1 Úvod}

Digitální technologie se prakticky využívají v každém odvětví, proto je potřeba na tuto skutečnost adekvátně reagovat i ve vzdělávacím procesu na školách. Znalosti v této oblasti mohou žákům velmi pomoci, a to zejména $\mathrm{v}$ prostorové představivosti. (Fadrhonc \& Honzíková, 2018)

Předmět Pracovni činnosti může být obecně veřejností vnímán jako předmět čistě spojený s manuální činností v dílně. Popsaný př́iklad dobré praxe ukazuje, že tomu tak být nemusí. V dnešní době 3D technologie dokážou výuku pracovních činností nejen zpestřit, ale zejména jí dát nový rozměr a žáky pro techniku více nadchnout. Některé žáky to může motivovat ke studiu na technicky zaměřených středních, př́padně vysokých školách, což by bylo v dnešní společnosti, kde je vysoká poptávka po technicky vzdělaných lidech, velmi perspektivní a žádané.

Př́íspěvek je zaměřen na příklad dobré praxe $\mathrm{v}$ oblasti 3D modelování a 3D tisku na základní škole $\mathrm{v}$ kontextu aktuálního Rámcového vzdělávacího programu i nově připravovaného předmětu Technika.

Inspirací textu je publikovaný článek, který se zabývá problematikou programování CNC strojů na vysoké škole (Čuboňová \& Náprstková, 2018). Stejně jako vysoké školy řeši volbu softwarového a hardwarového vybavení i základní školy potřebují př́íklady dobré praxe.

\section{Cíl}

Cílem studie je uvést příklad úspěšně provedeného zavedení aktuálních moderních technologií do oblasti výuky na základní škole, kdy žáci byli konfrontováni se základy 3D modelování a 3D tisku. Jedná se o jednu z možností, jak efektivně využít moderní technologie ve výuce a zároveň zábavnou formou žáky učit novým věcem, se kterými se v budoucnu většina $\mathrm{z}$ nich setká, at' už na střední či vysoké škole nebo obecně v životě. Ve vzdělávací oblasti „Člověk a svět práce“ v tematickém okruhu „Práce s technickými materiály“ je jedním z uvedených výstupů „užívá technickou dokumentaci, připraví si vlastní jednoduchý náčrt výrobku“. Zároveň je v tematickém okruhu „Design a konstruováni“" uveden i očekávaný výstup ,navrhne a sestaví jednoduché konstrukčni prvky a ověŕi a porovná jejich funkčnost, nosnost, stabilitu aj.“. (Rámcový vzdělávací program pro základní vzdělávání, 2017)

Současně se s možností zavádění nového předmětu „Technika“, který by měl být součástí studijní oblasti „Člověk a technika“, uvádí jako náplň výuky tohoto předmětu na druhém stupni „využiváni $3 D$ tiskárny“ a také ,poskytnutí prostoru pro rozvoj technické představivosti, modelováni a znázorňováni představ, jejich konstruováni $z$ vhodných materiáli̊, ...". (Dostál, 2018)

\section{$33 D$ modelování}

3D modelování je proces tvarování a vytváření 3D modelu pomocí CAD systému. Computer-Aided Design (CAD), neboli počítačem podporované projektování, je práce s pokročilým grafickým programem pro projektování. (Horová, 2008)

Během konstrukce je používán stejný software pro tvorbu součásti, výkresu, animace... CAD systém vznikl prvoplánově jako software pro navrhování integrovaných spojů v počítačích, až později našel uplatnění mimo jiné i ve strojírenství a architektuře, 
kde se jednalo o navrhování součástí a staveb. Později se software CAD začal používat v geodézii, kartografii a geografických informačních systémech. Objevení CAD technologií kvalitativně posunulo metodiku konstruování. 3D modeláře výrazně rozšiřují možnosti konstrukce, např́klad ve výkresové dokumentaci nebo vytvoření realistických součástí. Během 3D modelování lze libovolně měnit rozměry i součásti, ale také vidět a ověřovat základní technické parametry modelovaných součástí (sestav). (Sosna, 2015)

Výhodou 3D modelování je jeho další možná návaznost na následné technologické činnosti. Jedním $\mathrm{z}$ prríkladů mohou být komplikované tvary současných výrobků automobilového průmyslu. Nelze je vytvořit bez složitějších nástrojů vyrobených právě s pomocí řídicích systémů obráběcích strojů, které jsou úzce propojeny s konstrukčním systémem. Tento proces je obecně označován jako CAM (Computer Aided Manufacturing). (Fořt \& Kletečka, 2000)

Při zavádění 3D modelování na základní školy byly žákům v průběhu akčního výzkumu $\mathrm{k}$ dispozici různé programy pro modelování.

SketchUp je software pro tvorbu 3D modelů od společnosti Trimble, který je kompatibilní s platformou Microsoft Windows. Jeho největší předností je, že je zdarma pro výukové i soukromé účely, což může být ve školství jeden z rozhodujících faktorů. Další výhodou je poměrně krátká doba osvojování základních funkcí a orientace v programu. (Honzíková, 2016)

Jako komerční řešení byl zvolen CAD od firmy Dassault Systèmes, S. A. Vélizy, Francie. SolidWorks pro 3D modelování přináší velmi dobré konstrukční funkce a intuitivní uživatelské rozhraní pro urychlení konstrukčního navrhování a dosažení rychlé produktivity. Není sice zdarma, ale existuje tzv. Education Edition, což je licencovaná verze na jeden rok pro střední a vysoké školy a nově i pro základní školy. (Vláčilová, Vilímková, \& Hencl, 2006)

Alternativou k SolidWorks je CAD systém od společnosti Autodesk. Inventor také nabízí profesionální nástroje pro 3D modelování, dokumentaci a simulaci produktů. Je velmi efektivní, a to zejména díky mimořádné kombinaci parametrických, př́mých, volných a na pravidlech založených funkcích. (Fořt \& Kletečka, 2007)

\section{3D tisk}

3D tisk je aditivní proces tvorby třídimenzionálních pevných objektů z digitálního souboru, který je připraven v libovolném 3D modeláři a exportován do digitálního souboru stl, obj, amf, 3mf... (Cheng et al., 2016)

Objekt je vytvořen pokládáním souvislých vrstev materiálu, dokud není celý projekt dokončen. Aktuálně nejdiskutovanějším principem tisku je FFF/FDM. Fused Filament Fabrication (FFF) či Fused Deposition Modeling (FDM) je extrudování materiálu na tiskovou podložku. Tiskovým materiálem je převážně termoplast, který je ve výchozím stavu v pevném skupenství ve formě strun (filamentu). Nejčastěji používaným tiskovým materiálem je PolyLactic Acid (PLA), což je biologicky rozložitelný polyesterový výrobek $\mathrm{z}$ rostlinných materiálů. (Wittbrodt \& Pearce, 2015)

Prostá tvorba nákresu 3D modelu není pro žáky tolik zajímavá v kontrastu s možností zapojení jemné motoriky při doteku s reálným tělesem, které bylo vymodelováno v CAD programu a vytisknuto na 3D tiskárně. (Krotký, 2017) 


\section{3D tiskárny}

3D tiskárna je zařízení navržené pro Rapid Prototyping, což lze volně přeložit jako systém zrychleného návrhu a výroby prototypů. Nejzásadnějším přínosem $3 \mathrm{D}$ tisku je možnost vytvořit, respektive vytisknout prakticky jakoukoliv konstrukci. Při $3 \mathrm{D}$ tisku vzniká jen nepatrné množství odpadního materiálu. Naproti tomu dosud používané způsoby jako obrábění (vrtání, frézování,...) potřebují na začátek blok materiálu, ze kterého postupně odebírají. Subtraktivní výroba kromě finálního výrobku vytvoří i nezanedbatelné množství odpadu. (Chua \& Leong, 2017)

Při zavádění 3D modelování a 3D tisku na základní školy bylo využito několik druhů 3D tiskáren.

První tiskárnou byl Printrbot, stavebnice ze startupového projektu Kickstarter s názvem Printrbot pracující s extruderem pro $3 \mathrm{~mm}$ filament. Doporučeny jsou převážně ABS (AkrylonitrilButadienStyren) a PLA tiskové struny. Tiskne se na sklo a kalibrace se provádí pomocí distančních šroubků. („Printrbot: Your First 3D Printer“, 2020)

Oproti tomu uzavřený koncept tiskárny MakerBot Replicator $2 X$ umožňuje tisk za konstantní teploty a lze na něj nahlížet jako na profesionální komerční řešení. Tiskárna byla zvolena s představou bezobslužného využívání. (Sanjayani, Nazari, \& Nematollah, 2019)

Nejnovější tiskárna, která byla využita při výzkumu, je Original Prusa i3 $M K 2$, v době psaní článku již nahrazena verzí MK3S. Tiskárna, která získala mnoho ocenění a je jednou z neprodávanějších a nejoblíbenějších domácích tiskáren. (Stříteský, Průša, \& Bach, 2019)

\section{Metody}

Užitou metodou byl akční výzkum probíhající po dobu 3 let. Jak uvádí D. Nezvalová (2008), ,akční výzkum usnadňuje profesionální růst učitele. Učitelé se jeho pomocí učí ze své praxe. Tento fakt vede $k$ posílení jejich profesionálního růstu. Akční výzkum je považován za prostředek $k$ zvládnutí procesu změny, zlepšováni kvality a neustálého zdokonalováni školy“. Hlavní myšlenkou je, že se učitelé stávají zodpovědnými za neustálé zdokonalování školy. (Nezvalová, 2008)

V akčním výzkumu jsou základními prvky akce, reflexe a revize. Ty lze rozdělit na pět kroků, které se neustále opakují pro provedení jednoho kompletního cyklu: plánování, činnost, pozorování, reflexi a nové plánování. (Nezvalová, 2008)

V rámci plánování byl vypsán nový volitelný předmět 3D modelování a 3D tisk. Po otevření předmětu byli žáci pozorováni při práci s 3D modelářem a obsluhou 3D tiskárny. Ke konci hodiny byla s žáky diskutována jejich práce v polostrukturovaných rozhovorech. Na základě reflexe byly stanoveny nové plány v softwarovém a hardwarovém vybavení. Tento cyklus probíhal několikrát za školní rok.

Role učitele je v tomto výzkumu nesmírně důležitá, např́klad Noffke a Zeichner (1987) konstatují, že akční výzkum zvyšuje sebepojetí a odpovědnost učitelů a rozšiřuje jejich pohled na vzdělávání a společnost. Smysl pro osobní odpovědnost za vlastní růst profesionality, úsilí o zkvalitnění výuky, vedoucí k lepším vzdělávacím výsledkům žáků jsou nezanedbatelnými výsledky akčního výzkumu.

Monologické metody zahrnovaly vysvětlování a popis. Dialogické metody se opíraly o výukový rozhovor, motivační rozhovor a opakovací rozhovor. Výukový rozhovor byl 
využíván během celého průběhu výzkumu, kdy žáci diskutovali o problematice tisku a odpovídali na otázky vztahující se k tématu. (Horáček, 2017)

\section{Výsledky}

Tři školní roky za sebou (2015/2016, 2016/2017, 2017/2018) byla výuka 3D modelování a 3D tisku pilotována na základní škole Planá nad Lužnicí, okres Tábor. Zároveň běží již druhý rok za sebou (2018/2019, 2019/2020) na Základní škole Matice školské, České Budějovice.

$\mathrm{K}$ realizaci byl na ZŠ Planá nad Lužnicí v rámci nabídky volitelných předmětů nově zařazen předmět 3D modelování a 3D tisk. Výzkumný vzorek tvořila heterogenní skupina žáků druhého stupně, od šestého do devátého ročníku. Ve volitelném předmětu bylo vždy několik dívek i chlapců, z každé trrídy daného ročníku, kteří si tento volitelný předmět vybrali.

Na ZŠ Matice školské byla výuka 3D modelování a 3D tisku implementována do předmětů informatika a pracovní činnosti. Výzkumný vzorek tvořili žáci 6 . - 9. tř́́dy (heterogenní skupina žáků), kteří pracovali $\mathrm{s} C A D$ programem jako $\mathrm{s}$ modeláŕem $\mathrm{v}$ pracovních činnostech a jako grafickým programem $\mathrm{v}$ informatice. Během těchto předmětů byli žáci rozděleni na dvě skupiny, jednalo se tedy vždy o polovinu tř́́dy. „Po obsahové stránce je $3 D$ modelování v podstatě nadstavbou výnky práce s grafikou $v$ grafických editorech." (Honzíková, 2016)

V rámci akčního výzkumu byly analyzovány různé modelovací programy. Prvotní výběr byl stanoven podle nejpoužívanějších programů pro $3 \mathrm{D}$ modelování a $3 \mathrm{D}$ tisk ("Software \& Software Reviews For Business \& Nonprofit", 2020). Obdobně byla pozornost zaměřena na různé 3D tiskárny, přesněji pak na jejich sestavení, nastavení a obsluhu žáky. Výběr byl řízen cenou, možností koupě v České republice a žebříčkem nejlepších hobby FDM tiskáren (“Best 3D Printer", 2018).

Výsledky jsou rozděleny dle jednotlivých školních let, kdy probíhala výuka a zkoumání. Větší prostor je věnován ZŠ Planá nad Lužnicí, kde probíhala výuka primárně na vzorku 25 žáků každý školní rok, tedy 75 celkově. Volitelný předmět se těšil vysoké oblibě a velikost skupiny byla definována vybavením učebny, 25 počítači. Žákům nebylo umožněno zapsat si předmět vícekrát, i když dvě třetiny projevili zájem nový školní rok i roky následující.

Ve výuce byly zadávány úkoly seznamující žáky se základními principy tvorby skici a prvku. Po úvodních seznamovacích hodinách si žáci mohli po domluvě s vyučujícím volit vlastní zadání či se věnovat společnému tématu. Na konci školního roku bylo minimální získanou úrovní vytvoření modelu pomocí příkazů přidat/odebrat vysunutím. Model navrhnout, aby ho bylo možné vytisknout, připravit pro tisk a vytisknout z PLA. Více jak polovina žáků využívala pokročilejší funkce, které se naučili podle videonávodu na video portále Youtube či na základě ukázky předvedené vyučujícím. S databázovými servery s volně dostupnými modely byli žáci seznámeni až v polovině druhého pololetí s úkolem vyhledat a vytisknout jeden model $\mathrm{z}$ databáze. Důraz byl kladen na tisknutí vlastních modelů, modelů navržených samotným žákem nebo podle předlohy vyučujícího.

Jako kontrolní škola byla zvolena ZŠ Matice školské v Českých Budějovicích, kde bylo celkově zapojeno 68 žáků za rok v rámci předmětů Informační technologie a Pracovní 
činnosti. Jednalo se o dvě skupiny $\mathrm{v}$ informatice a dvě skupiny v pracovních činnostech. Velikost každé skupiny byla 17 žáků, což byla maximální kapacita učebny informatiky.

Na obou školách vedli výuku vyučující (autoři studie), kteří mají s 3D modelováním a 3D tiskem několikaletou zkušenost a pracují s 3D programy a 3D tiskárnami i mimo základní školy.

Studie posloužila jako zpětná vazba výukových metod pro vyučující, kteří si mohli ověřit, že jimi navrhované metody pro výuku 3D modelování na základních školách byly pro žáky srozumitelné a odrazily se na jejich zájmu a aktivitě při výuce. Během rozhovorů na konci výuky byly žáky reflektovány jejich názory na jednotlivé 3D tiskárny a 3D modeláře, které jsou uvedeny v jednotlivých školních ročnících.

\section{Školní rok 2015/2016}

Od první hodiny byli žáci konfrontováni s 3D modelováním a 3D tiskem. $\mathrm{V}$ rámci modelování procházeli jednoduchými př́klady, které je seznamovaly $\mathrm{s}$ tvorbou prostorových modelů pomocí tlačení a táhnutí (Push/Pull), které je typické pro SketchUp. Program vyniká velmi rychlým zorientováním v prostředí pro nového uživatele. Zásadní nevýhodou byl složitý export modelu do STL kvůli nutnosti doinstalování externího pluginu nebo potřeba ovládat u novějších verzí anglický jazyk. V roce 2020 je SketchUp př́istupný $\mathrm{v}$ internetovém prohlížeči $\mathrm{v}$ anglickém jazyce a obsahuje export do STL. $\mathrm{V}$ pokročilejších modelech žáci negativně hodnotili pro ně komplikované a nelogické postupy nutné $\mathrm{k}$ tvorbě.

Každou vyučovací jednotku se měnící skupina čtyřech žáků vždy věnovala sestavě stavebnice tiskárny Printerbot. Do práce a sestavení často zasahoval vyučující a po provedení polostrukturovaného rozhovoru lze vyslovit velmi negativní závěr: všichni žáci hodnotili tuto tiskárnu jako neatraktivní a komplikovanou na obsluhu bez nutkání s ní pracovat $\mathrm{v}$ budoucnu.

V polovině školního roku byla vybraná skupina konfrontována $\mathrm{s}$ možností práce v parametrickém CAD programu SolidWorks. Většina žáků dosáhla znalostí tvorby objektů pomocí přidání a odebírání vysunutím a rotací. Nadaní žáci si vyzkoušeli príklady na tažení po křivce a spojování profilů. Zásadní výhodou pro rychlejší osvojení práce s programem a navrhování modelů bylo absolvování pracovních činností v osmém ročníku, kde se žáci seznámili s technickým kreslením. Tvorba složitějších modelů a export do STL byl $\mathrm{v}$ tomto prípadě jednodušší a tento fakt byl ověřen další školní roky se stejným výsledkem.

\section{Školní rok 2016/2017}

V následujících letech byla žákům představena možnost práce v programu SketchUp a SolidWorks. V hodinách byly voleny př́íklady, které bylo možné modelovat ve všech programech a žáci mohli kdykoliv přecházet $\mathrm{z}$ jednoho prostředí do druhého.

Žákům byla v novém školním roce představena tiskárna MakerBot Replicator 2X. Po půl roce žáci hodnotili práci $\mathrm{s}$ tiskárnou jako snazší, ale neatraktivní vzhledem $\mathrm{k}$ uzavřenosti celého konceptu. Př́ závěrečných rozhovorech oceňovali vyšší spolehlivost tisku na úkor nemožnosti cokoliv ovlivnit bez pomoci učitele.

$\mathrm{V}$ polovině pilotáže, po roce a půl školního roku, byla do předmětu zakoupena tiskárna Original Prusa i3 MK2. Stejně jako v př́padě Printrbota se jednalo o stavebnici. Tiskárnu, 
mimo kontrolu základní desky, postavili žáci bez pomoci učitele a provedli i potřebné kalibrace. $\mathrm{V}$ dalších pololetích byla stavebnice několikrát rozebrána a složena různými skupinami.

\section{Školní rok 2017/2018}

Třetí rok byly žákům $\mathrm{k}$ dispozici různé modelovací programy, SketchUp $6 \mathrm{Cz}$, SketchUp Make 2017, SolidWorks 2018 a Inventor 2018. K tisku mohli využít tiskárny Printrbot, MakerBot Replicator 2X a Original Prusa i3 MK2.

$\mathrm{Na}$ základě rozhovorů a pozorování byla jako vhodná kombinace pro výuku na ZŠ zvolena tiskárna Original Prusa i3 MK2 a CAD systém SolidWorks. Všechny následující diskuze a pozorování dalších skupin vyzdvihovaly jednoduchost ovládání a celkovou př́ivětivost. Žáci kontrolní školy Matice školské hodnotili stejným způsobem alternativu ke CAD SolidWorks $\mathrm{v}$ podobě Autodesk Inventor. Způsob tvoření je obdobný a v základních úkonech je možné pozorovat minimální odchylky postupů tvorby.

\section{Závěr}

Prezentované řešení je př́íkladem dobré praxe v rozvoji 3D modelování a 3D tisku na druhém stupni základní školy. Výsledkem akčního výzkumu je doporučení využít pro modelování parametrické CAD systémy typu SolidWorks či Inventor. Z obrovské nabídky 3D tiskáren lze doporučit stavebnici tiskárny Original Prusa i3 MK.

Zkvalitnění a zatraktivnění výuky je důležitým prvkem současného vzdělávacího procesu. Žáci 2. stupně základních škol byli seznámeni s další možností moderního uchopení výuky implementováním 3D modelování a 3D tisku do výuky na základní škole.

Popsaný př́íklad je možné vnímat jako doporučení pro jiné ZŠ zabývající se uvedenou problematikou, jak podobnou výuku koncipovat, jaké prvky je možné použít, jak do výuky zapojit aktuální technologie.

\section{Literatura}

Best 3D Printer [Online]. (2018). Retrieved October 26, 2019, from https://all3dp.com/1/best-3d-printer-reviews-top-3d-printers-home-3-d-printer-3d/

Čuboňová, N., \& Náprstková, N. (2018). Example of Good Practice in Support Education of CNC Machine Programming at Technical University. Journal of Technology and Information Education, 10(1), 63-72. https://doi.org/10.5507/jtie.2018.005

Dostál, J. (2018). Podkladová studie: Člověk a technika [Online]. Praha: NUV. Retrieved from http://www.nuv.cz/file/3517_1_1/

Fadrhonc, J., \& Honzíková, J. (2018). The Current State of Research Spatial Imagination of the Students of the Primary School in the Context of 3D Modeling [Online]. Journal of Technology And Information Education, 10(2), 108-122. https://doi.org/10.5507/jtie.2019.002

Fořt, P., \& Kletečka, J. (2007). Autodesk Inventor: funkční navrhování v průmyslové praxi (2., aktualiz. vyd). Brno: Computer Press.

Fořt, P., \& Kletečka, J. (2000). Mechanical Desktop 4: učebnice. Praha: Computer Press. Cheng, G. Z., San Jose Estepar, R., Folch, E., Onieva, J., Gangadharan, S., \& Majid, A. (2016). Three-dimensional Printing and 3D Slicer [Online]. Chest, 149(5), 1136-1142. https://doi.org/10.1016/j.chest.2016.03.001 
Chua, C. K., \& Leong, K. F. (2017). 3D printing and additive manufacturing: principles and applications. New Jersey: World Scientific.

Honzíková, J. ed.; Simbartl, P. ed. Olympiáda techniky Plzen̆ 2015 19.-20.5. 2015: sborník příspěvků $\mathrm{z}$ mezinárodní studentské odborné a vědecké konference. 1. vyd. Plzeň: Západočeská univerzita v Plzni, 2015, s. [198-200]. ISBN 978-80-261-0519-0.

Honzíková, J. ed.; Simbartl, P. ed. Olympiáda techniky Plzen̆ 2016 17.-18.5. 2016: sborník příspěvků z mezinárodní studentské odborné a vědecké konference. 1. vyd. Plzeň: Západočeská univerzita v Plzni, 2016, s. [244-250]. ISBN 978-80-261-0620-3.

Horáček, P. (2017). Využití $3 D$ tisku v technické výchově na ZŠ, Brno

Horová, I. (2008). 3D modelování a vizualizace v AutoCADu pro verze 2009, 2008 a 2007.

Brno: Computer Press.

Krotký, J. (2014). 3D tisk v prípravě budoucích učiteli̊. TVV, 7(1), 210-213.

Nezvalová, D. (2008). Akční výzkum ve škole [Online]. Pedagogika, 2003(3), 300-308

Noffke, S., Zeichner, K. (1987). Action research and teacher thinking. Paper presented at the annual meeting of the American Educational Research Association, Washington, DC.

Printrbot: Your First 3D Printer [Online]. (2020). Retrieved February 03, 2020, from https://www.kickstarter.com/projects/printrbot/printrbot-your-first-3d-

printer?fbclid=IwAR0mR5ylQxF_GG4KoEvrULCSjXcbSvNyZNh_ZYrhVCqb3VwD8 Y-RXv59Da4

Rámcový vzdělávací program pro základní vzdělávání [Online]. (2017). Retrieved November 08, 2019, from http://www.msmt.cz/file/43792/

Sanjayani, J., Nazari, A., \& Nematollah, B. (2019). 3D concrete printing technology: construction and building applications. Oxford: Butterworth-Heinemann.

Software \& Software Reviews For Business \& Nonprofit [Online]. (2020). Retrieved March 26, 2020, from https://www.capterra.com/

Sosna, T. (2015), Techniky tvorby sestav ve vybraných CAD systémech v př́kladech se zaměrením na $3 D$ modeláre Inventor a SolidWorks

Stř́teský, O., Průša, J., \& Bach, M. (2019). Základy 3D tisku s Josefem Průšou [Online]. Praha: Prusa Research. Retrieved from https://www.prusa3d.cz/wpcontent/uploads/zaklady-3d-tisku.pdf

Vláčilová, H., Vilímková, M., \& Hencl, L. (2006). SolidWorks. Brno: Computer Press.

Wittbrodt, B., \& Pearce, J. M. (2015). The effects of PLA color on material properties of 3-D printed components [Online]. Additive Manufacturing, 8, 110-116. https://doi.org/10.1016/j.addma.2015.09.006 